\title{
¿HÉROE O VILLANO? \\ PORFIRIO DÍAZ, CLAROSCUROS. \\ UNA MIRADA DESDE \\ LA CARICATURA POLÍTICA*
}

\author{
Fausta Gantús
}

Instituto de Investigaciones Dr. José María Luis Mora

I a caricatura política constituye una vía de acceso al Lconocimiento histórico en tanto se ocupa de los temas candentes y personajes relevantes del momento en que fue generada. Pero la caricatura no es ni la crónica dae los hechos ni un testimonio de los mismos. ${ }^{1}$ Constituye la

Fecha de recepción: 31 de mayo de 2015

Fecha de aceptación: 11 de agosto de 2015

* Agradezco a Elisa Cárdenas Ayala los diálogos que me permitieron pensar en varias de las aristas que aquí desarrollo; con ella y con Alicia Salmerón estoy en deuda porque sus observaciones a un par de versiones de este artículo resultaron fundamentales para darle su forma final. También reconozco las aportaciones de Laurence Coudart y de los integrantes del Seminario permanente interinstitucional de Historia Política que se realiza en el Instituto Mora, en cuyo marco se discutió este texto en su sesión de abril de 2015, sus comentarios sirvieron para enriquecerlo. ${ }^{1}$ Las caricaturas dan cuenta de la realidad pero no son testimonio de esa realidad - en todo caso lo son pero de una manera incidental-, si consideramos que un testimonio tiene como pretensión básica ser un reflejo puntual y fidedigno de la realidad que presenta - como en su caso lo pretendió, o se le atribuyó, por mucho tiempo a la pintura naturalista o, 
expresión y la opinión de un individuo y de un grupo, y es siempre, por tanto, una visión sesgada y cargada de intencionalidad política. Cuando estudiamos historia a partir de este tipo de documentos, debemos tener presente, muy presente, que comunican una opinión, y que ésta es parcial. ${ }^{2}$ Su perspectiva refleja el sentir de pequeños o amplios núcleos, según sea el caso, pero de ninguna manera representa el de la sociedad, sino el de una parte de ella, y tiene una pretensión básica: busca incidir en el ánimo de los receptores y moldear su percepción.

No es la caricatura, por tanto, testimonio de la realidad, sino una construcción de esa realidad. Lo que expresa debe ser leído en esos términos. Si bien las imágenes atienden asuntos o temas que están en el ambiente y toman elementos de los sucesos y acontecimientos cotidianos para elaborar sus críticas, también subliman, exageran, deforman, adecúan el tratamiento a conveniencia de quienes las producen. En tal sentido, las caricaturas políticas son vehículos de representación y, sobre todo, instrumentos para actuar sobre la sociedad y condicionar las percepciones individuales y colectivas. ${ }^{3}$

en especial, a la fotografía, por ejemplo-, en tanto las caricaturas constituyen una elaboración a partir de la realidad.

${ }^{2}$ La principal diferencia con otro tipo de fuentes, en general, y con otras fuentes visuales, en particular, ante lo cual el estudioso que trabaje con ellas debe estar prevenido, es que en el momento en que fueron generadas las caricaturas no persiguieron transmitir información. La información la proporcionan al historiador porque aluden a la realidad que las generó; pero debemos tener claro que las caricaturas no tuvieron pretensión ni de objetividad ni de veracidad y que son, esencialmente, una interpretación, matizada por la sátira y la ironía, de esa realidad a la que apuntan. ${ }^{3}$ Sobre el tema de la caricatura hemos discutido ampliamente en GANTús, Caricatura y poder político. 
A lo largo de la vida pública de Porfirio Díaz, y en especial durante el régimen que encabezó en su calidad de presidente de la República, se produjeron diversos periódicos satíricos e ilustrados, entre ellos algunos que incluían el uso de la caricatura como parte de su estrategia de apoyo o de crítica. El propósito de este trabajo es acercarnos a esos impresos para descubrir cómo, para exaltarla o denostarla, según fueran producidos por correligionarios o por opositores, la imagen del militar fue dibujada de manera reiterada presentando visiones contrastantes sobre el mismo. El análisis de esas representaciones posibilita entender la forma en que sus contemporáneos percibieron a Díaz o, para ser más precisos, la manera en que trataron que fuera percibido. En ese contexto, las caricaturas nos permiten desentrañar las visiones dicotómicas que sobre el personaje se construyeron durante su propia época, y entender el nacimiento de algunas que permearon la discusión historiográfica, la del momento y la posterior. ${ }^{4}$

\footnotetext{
${ }^{4}$ Sobre el régimen de Porfirio Díaz existe una amplia historiografía; para un acercamiento a la misma remitimos a dos obras fundamentales que dan cuenta de ella. Una es el trabajo pionero de Cosío Villeggas, "El Porfiriato: su historiografía o arte histórico", 1949, corregido y aumentado posteriormente; la otra, un balance reciente de Tenorio Trillo y Gómez Galvarriato, El Porfiriato, 2006.

Sin desconocer la amplia producción en torno a la época y al personaje, pero en razón de las limitaciones de espacio que harían imposible una enumeración exhaustiva, en lo que se refiere a la historia del periodo, una obra esencial continúa siendo la Historia moderna de México coordinada por Daniel Cosío Villegas, en particular interesan a los temas que se desarrollan en este artículo los dos volúmenes dedicados a la "Vida política interior". Cosío Villegas, El Porfiriato. La vida política interior, primera y segunda partes. Otras obras de referencia obligada son las de Valadés, El Porfirismo: historia de un régimen; y la de Guerra, México: del Antiguo Régimen a la Revolución.
} 


\section{LA CONSTRUCCIÓN DE UNA EPOPEYA}

Elegantemente ataviado en su traje militar, con la espada a la cintura, parado firme sobre sus pies, y con el gesto serio, pleno de convicción, mediante un fuerte apretón de manos Porfirio Díaz sella con Vicente Riva Palacio un pacto: la alianza para la defensa del sufragio libre y la no reelección $y$, especialmente, para la salvaguarda de los principios constitucionales, consignados en el texto fundamental decretado en 1857. Esto queda de manifiesto en el estandarte que ondea detrás, y al medio, de ambos personajes. Al fondo, en la parte inferior, el sol desaparece en el poniente; el astro que va perdiendo su brillo lleva grabado el rostro de Sebastián Lerdo de Tejada, fórmula del caricaturista para destacar el fin del dominio de este gobernante (imagen 1). Este detalle, el de la crítica burlesca, es el que da el tono satírico a la imagen y la convierte, más allá de su carácter panegírico, en una caricatura. El uso de este recurso, el de la convivencia del halago y la crítica en el mismo recuadro de la sátira visual, dio forma a un tipo de caricatura híbrida, que permitió atacar y defender en la misma representación; esto es, posibilitó una estrategia de acción periodística basada en la articulación de un doble mensaje - enaltecimiento de unos y denostación de otros actores y situaciones - proyectado desde una sola obra.

Esa representación apareció el 26 de mayo de 1876, en el semanario El Abuizote, con el título "La unión da la fuerza” y alude, sin mencionarlo abiertamente, al Plan de Tuxtepec y al movimiento asociado al mismo que había estallado en enero de ese año y en el que participaban como promotores y líderes tanto Díaz como Riva Palacio. La rebelión 


\section{Imagen 1}

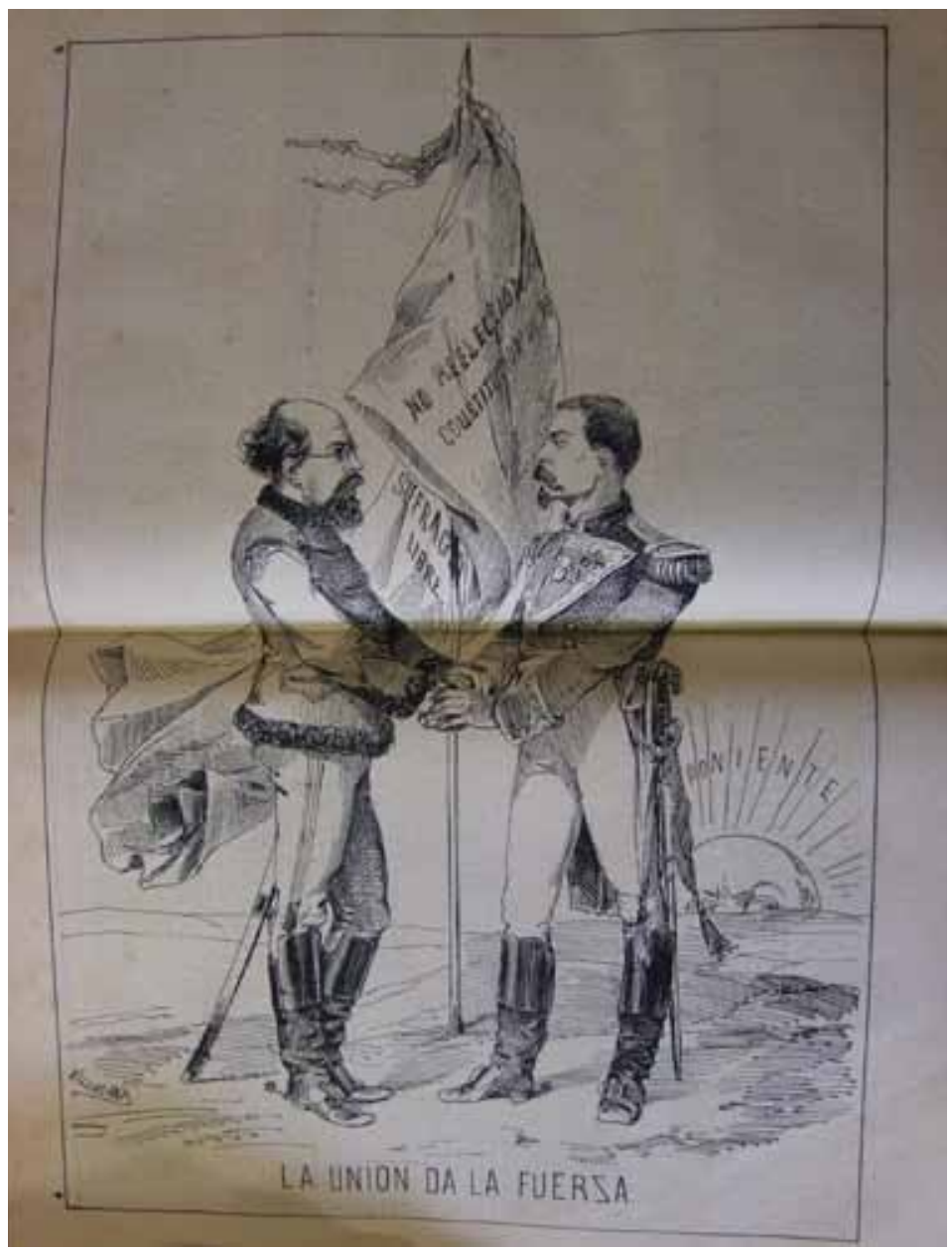

“La unión da la fuerza”, El Abuizote (26 mayo 1876). 
de Tuxtepec tuvo como característica fundamental la de ser un movimiento contra la reelección del entonces presidente Lerdo. En el momento, la reelección tenía estatus de constitucional, pero se oponía a las aspiraciones de acceder al gobierno de una generación de políticos más jóvenes que la de Lerdo y, de manera muy especial, a la de Díaz, quien desde tiempo atrás - desde los comicios de 1867- había perseguido, sin éxito, ocupar la primera magistratura del país. Por su parte, El Abuizote era un semanario satírico que desde 1874 había hecho una feroz campaña contra la administración lerdista - objetivo para el que fue creadoy que apoyaba el movimiento rebelde contra el gobierno. ${ }^{5}$ La redacción la compartían el propio Riva Palacio y el dibujante José María Villasana, quien tenía a su cargo la realización de las caricaturas; ambos se caracterizaron en términos de sus filiaciones políticas por su acendrada lealtad a Díaz.

Durante sus primeros años de vida político militar, años de búsqueda de acceso al poder, en particular en el marco de la coyuntura político electoral de 1876, los partidarios de Díaz se dieron a la tarea de construir y proyectar, desde las páginas de los periódicos, su imagen como la de un líder político, defensor del pueblo y de la patria. Por medio de las caricaturas se le presentó también como el impulsor del principio de la no reelección, mediante el cual se garantizaría una dinámica de relevo periódico de autoridades gubernamentales que posibilitaría el inicio de una nueva época para el país signada por la paz. El de la no reelección fue un principio que el mismo Díaz repudiaría, unos años más tarde, en su intento

${ }^{5}$ El Abuizote fue un importante instrumento de combate del grupo opositor al lerdismo. Se publicó de 1874 a 1876. 
por asegurar lo que seguía siendo una frágil estabilidad política, a más de satisfacer sus propias ambiciones de permanecer en la presidencia, pero en la década de 1870 fue su bandera. De esa forma, insinuaban las caricaturas, el probo militar pondría freno a las ambiciones personalistas del presidente Lerdo de Tejada y sus colaboradores. Díaz era representado como el protector de los principios constitucionales - aunque la reelección, como ya apuntamos, era constitucional- y como el salvador de la patria. El joven y casi apuesto Díaz adquiría así dimensiones heroicas que lo hacían ver como la esperanza de un porvenir mejor para México.

Otro aspecto que sirvió para legitimar y proyectar a Díaz como un personaje prometedor y carismático fue el de la asociación que, desde las páginas del mismo semanario, se construyó entre el militar y el pueblo. ${ }^{6}$ Díaz, oficial condecorado por su valor y su defensa de la nación, abanderando el Plan de Tuxtepec se solidarizaba con la causa popular, como lo muestra una caricatura sin título publicada en El Abuizote, el 1ํㅡㄹ de septiembre de 1876 (imagen 2). La espada del general está en las manos del Pueblo, al cual abraza. La representación adquiere un doble carácter simbólico. Por un lado, destaca la presencia de un determinado tipo de pueblo: el que se levanta en armas para defender a su patria de los abusos del poder; un pueblo en el que el ciudadano se transforma en soldado. El ciudadano convertido en soldado es el miliciano, precisamente al que Díaz había dirigido como parte de las guardias nacionales en la lucha contra la intervención

\footnotetext{
${ }^{6}$ Asociación que también se hacía en otros impresos que, entre otras cosas, lo llamarían "el soldado del pueblo". "La dictadura”, El Siglo Diez y Nueve (15 mar. 1877).
} 
francesa y el imperio de Maximiliano. Por el otro, ese pueblo participa de una lucha en particular: la que abandera el propio Díaz. Así, la presencia del pueblo en armas sirve para legitimar la rebelión en razón de su carácter supuestamente popular. El abrazo sella el pacto entre los dos actores y los une indisolublemente en el imaginario colectivo.

Un elemento más que enriquece a esta caricatura es el aspecto del hombre que simboliza al pueblo, el cual remite al del obrero de la época o, de manera más amplia, a los sectores industriosos. Ambos, ese industrioso Pueblo en armas, junto con Díaz, luchan por una causa común: la libertad, como queda expresado por el gorro frigio que se alza por encima de ellos y el título al pie del basamento sobre el cual se yerguen. Ambos, juntos, observan también el supuesto carácter que bajo el régimen lerdista han adquirido la "igualdad" y la "fraternidad", que han sido conculcadas y quedado reducidas al intercambio de favores y el otorgamiento de privilegios a los aliados y amigos del presidente (imagen 2). ${ }^{7}$

Díaz es representado como el noble militar, amigo del pueblo, que asume la tarea de protegerlo, a él y a los principios fundamentales heredados de la revolución francesa: "libertad, igualdad y fraternidad". La estrategia sirve también para equiparar, en el imaginario de los receptores, las dimensiones de la lucha tuxtepecana con las de la gesta gala.

7 En la crítica al régimen lerdista se valen del principio de la "igualdad" para equiparar su llegada al poder en 1876 con la del emperador Maximiliano en 1866, aludiendo así a su gobierno como de carácter monárquico. La "fraternidad" sirve para evidenciar el interés de los aliados de Lerdo por los puestos de gobierno, simbolizados en las "carteras" que abrazan, y con las que se solía representar en la caricatura las secretarías de Estado. 
Imagen 2

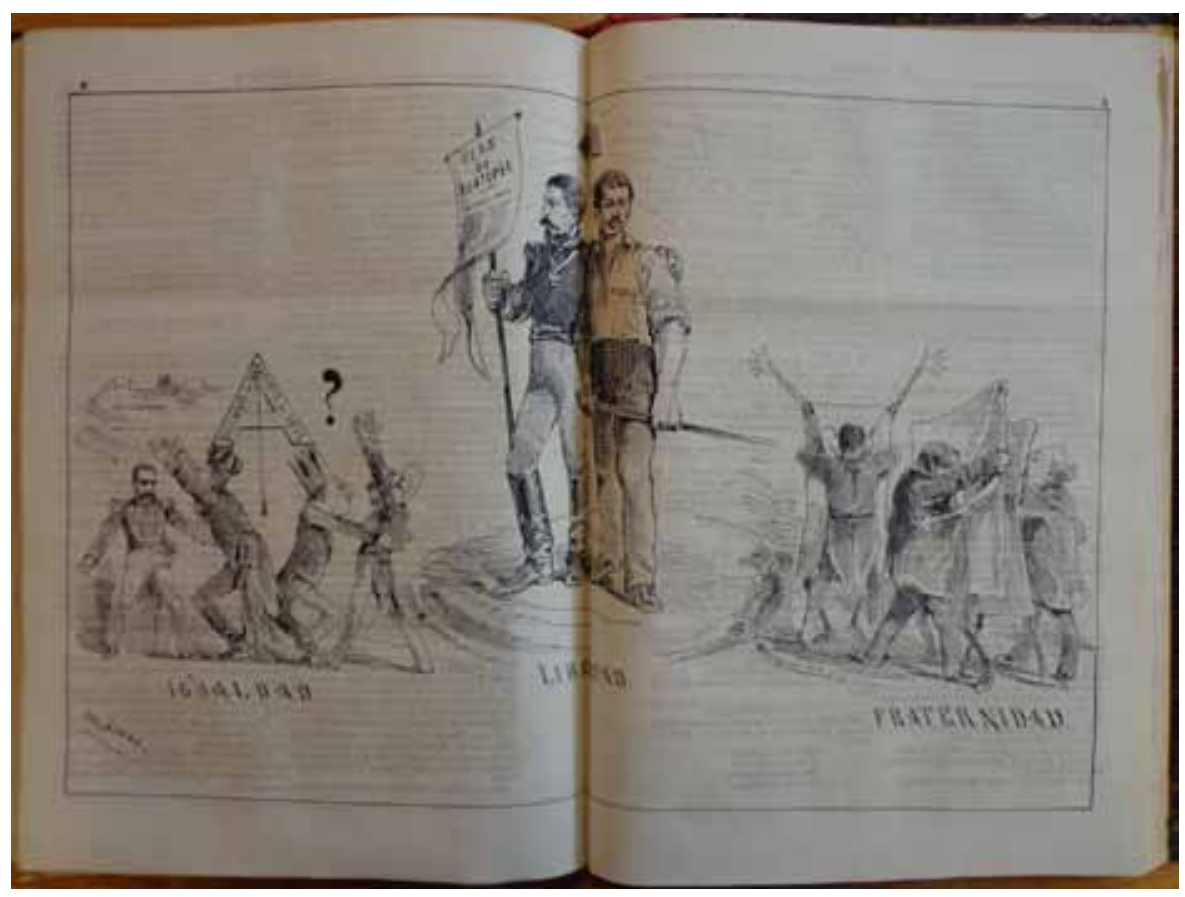

Sin título, El Abuizote (1ํㅗ. ${ }^{\circ}$ sep. 1876). 
También, al encarnar Díaz no sólo la defensa de la libertad sino la libertad misma, se deja entrever que su actuación en este escenario es la que permitiría recuperar los otros dos principios - "igualdad y fraternidad" - que habrían sido igualmente violentados por el gobierno lerdista, al que se acusa así de tiránico y despótico. El general adquiría la dimensión del hombre dispuesto a sacrificarse por la causa común, por la República y por el pueblo.

Mediante los trazos del lápiz de Villasana, en estas y otras caricaturas, se representó a Díaz como el guía y libertador del pueblo oprimido en su lucha contra un régimen gubernamental pernicioso. ${ }^{8}$ Sin duda, la asociación entre Díaz y el pueblo que se elaboraba desde las páginas del impreso tenía a su favor el apoyo popular con el que contaba el militar en su región por su carácter de líder de las guardias nacionales. Y también facilitaba la labor de proyectar la cercanía entre Díaz y el pueblo el hecho de que el presidente Lerdo fuera un gobernante al que la opinión general identificaba con los intereses financieros. Pero no fue El Abuizote el único impreso aliado y promotor de Díaz. También en ese año de 1876 El Padre Cobos, en varias caricaturas y con trazos muy similares a los de su colega satírico, lo mostraba como el general que comandaba al pueblo en la lucha contra el gobierno reeleccionista. ${ }^{9}$ Este periódico representó

8 Por ejemplo, sin título, El Abuizote (5 mayo 1876); "La aurora de la libertad" (1º dic. 1876); "México es libre ya..." (29 dic. 1876).

9 De enero de 1873 a julio de 1876 se publicó la tercera época de este semanario satírico. Aunque como responsable aparecía J. R. Torres, tras su elaboración se encontraba también Ireneo Paz, personaje siempre cercano a Porfirio Díaz en su etapa de lucha por el acceso al poder, y al régimen de gobierno que encabezó. 
también a Díaz como el militar que, con fuete y látigo en mano, hostigaba y vencía a las fuerzas oficiales opresoras, a pesar de las noticias difundidas por la prensa del gobierno, la cual insistía en la derrota de los pronunciados; o bien como el hombre adusto y serio que, a pesar de las facultades extraordinarias, otorgadas por el Congreso al presidente Lerdo para mantener el orden, logrará vencerlo. ${ }^{10}$

En esas caricaturas la figura de Díaz y sus allegados era prácticamente una reproducción del natural: en ellas el acento satírico estaba puesto en la derrota del enemigo, eran ellos y las situaciones en que estaban inmersos los que aparecían ridiculizados. La producción de imágenes como esas ayudó a construir, en la época - y en el contexto de un país necesitado de elaborar una historia nacional de la cual enorgullecerse y, por tanto, ávido de figuras heroicas - , las proporciones casi épicas de la figura de Díaz, quien sería conocido y reconocido como el "Héroe del 2 de abril", en referencia a su participación en una memorable batalla contra el imperio de Maximiliano.

Si bien podría considerarse que este tipo de imágenes, profundamente laudatorias, desaparecerían con el correr de los años, no fue así. A pesar de la renuncia de Díaz al principio de la no reelección y de su prolongada permanencia al frente del gobierno - actos ambos que contradecían la bandera con la que había llegado a la presidencia-, los grabados y aun las caricaturas elogiosas siguieron ocupando la páginas de algunos periódicos hasta el final del régimen.

10 En El Padre Cobos: "Paciencia Sres..." (4 jun. 1876); "Miren vuesas [sic] mercedes..." (9 ene. 1876); sin título [recuadro] (11 jun. 1876); "Se asusta de la mortaja..." (13 ene. 1876); "Últimas noticias..." (15 mayo 1876); "Un lorito...” (23 abr. 1876); entre otras. 
Continuaron publicándose a pesar de la consolidación del poder de Díaz, que podía hacerlas parecer como innecesarias, en el sentido de que él contaba ya con múltiples apoyos y legitimidad suficiente como para tener que seguir buscándolos por la vía de una suerte de propaganda impresa. Sin embargo, la crítica permanente - velada o abierta - que se hacía al mandatario y su gobierno desde otros impresos, tanto por medio de la palabra como de la imagen, hizo indispensable la permanencia de las representaciones visuales que lo enaltecían.

De diversos tipos - caricaturas, grabados, fotografías, pinturas-, pero siempre con carácter apologético, esas representaciones que dignificaban al general participaban de una especie de guerra de imágenes desarrollada entre los integrantes de la prensa, que desde los títulos que producían representaban los intereses de diferentes facciones y posiciones políticas. Las imágenes favorables al presidente eran la respuesta a los ataques directos que perseguían exhibir los defectos del régimen y las traiciones y pretensiones de la máxima autoridad; pero eran también la contraparte de otras representaciones laudatorias mediante las cuales los críticos de Díaz, con la intención de desmerecerlo, exaltaban a diversos personajes de la historia patria y del mundo de la política - desde Miguel Hidalgo hasta Melchor Ocampo, desde Ignacio Comonfort hasta Sebastián Lerdo de Tejada, deteniéndose especialmente en la figura de Benito Juárez.

Superada la difícil década de 1880 y a lo largo de todo su periodo de gobierno, impresos como La Patria Ilustrada continuaron mostrando al general en las caricaturas híbridas como el hombre que mantenía los equilibrios políticos y como promotor del desarrollo del país. Este tipo de 
representaciones celebratorias cobraron fuerza renovada en los últimos años de su gobierno, cuando las críticas al mandatario se multiplicaron y su caída era inminente. De esta manera, hacia fines del gobierno de Díaz los correligionarios del presidente aún recurrirían al uso de la gráfica para exaltar su figura, para pintarlo como el héroe de la nación, como el destacado estadista que había logrado posicionar a México en el ámbito internacional y, sobre todo y quizá en especial, para mostrarlo - gran ironía - como el amigo del pueblo y consolidar su asociación, la de la imagen presidencial, con las clases populares.

En una gráfica más, aunque no se trata de una caricatura, sino de un grabado - obra de José Guadalupe Posada - ${ }^{11}$ nos detendremos para mostrar el carácter apologético con el que se dibujaba a Díaz poco antes de su caída (imagen 3). Vale la pena fijarse en este grabado por los puentes que se tienden entre el principio y el final del régimen. Esto es, en tanto en las representaciones de 1876 se asoció al militar con el pueblo, con la defensa de la patria y de la Constitución, y se le pintó como el promotor de la paz, para 1910 se le mostraba como el artífice y constructor, y quien había logrado la consolidación de una era de progreso y orden, tal cual el lema que caracterizara su administración. También se le equiparaba con el héroe más distinguido del ideario mexicano, con el "Padre de la patria": Hidalgo.

11 La historiografía posrevolucionaria creyó entender a Posada como un acérrimo opositor al régimen de Díaz, pero trabajos posteriores han matizado y, en algunos casos, mostrado las contradicciones de su posición. Uno de los trabajos más interesantes en este sentido es el de BARAJAs, Posada: mito y mitote. 
Así, en San Lunes, el 3 de enero de 1910, se dibujaría al mandatario elegantemente ataviado con traje militar de gala y el pecho colmado de condecoraciones. Aparece encanecido y con el rostro surcado de arrugas, pero con el mismo gesto serio y pleno de convicción que mostraran las imágenes de sus años mozos, esas realizadas en 1876 , y con una de sus manos descansando sobre su espada, interesante signo que valida el uso de las armas como instrumento imprescindible para lograr las condiciones de paz que la nación había requerido y quizá requería. Díaz muestra a una pareja que, en apariencia, forma parte del pueblo trabajador, los logros de su gobierno. Logros que, como el título de la imagen sugiere - "Homenaje a Hidalgo" - , eran también el sueño del héroe de la independencia: la República dignificada por una era donde imperaban la libertad y la paz, el progreso - que queda expresado en el tráfico marino, la presencia de locomotoras que cruzan el paisaje mexicano y los cables de electricidad y telégrafo- y el trabajo para todos. ${ }^{12}$ Destaca el hecho de que la República mexicana, la patria misma, reposa en la silla presidencial, con lo cual se simboliza la fusión entre el presidente y la nación que son, así, uno solo (imagen 3).

12 El hombre y la mujer parecen, a primera vista, simbolizar a la familia mexicana. Sin embargo, un análisis detenido muestra que mientras el hombre está claramente caracterizado como un trabajador - obrero o artesano-, la mujer, cuyo vestido y peinado no corresponden al que caracterizaba a los sectores populares, representa la Paz, pues de su brazo izquierdo asoma un ramo de olivo.

Es interesante también observar en este grabado la relevancia del elemento mestizo, evidente en el trabajador, como expresión de lo mexicano. En cambio, el individuo de origen indígena aparece de espaldas y con una estatura reducida, y porta una especie de charola con flores, posible alusión a su relación con el mundo rural. 
Imagen 3

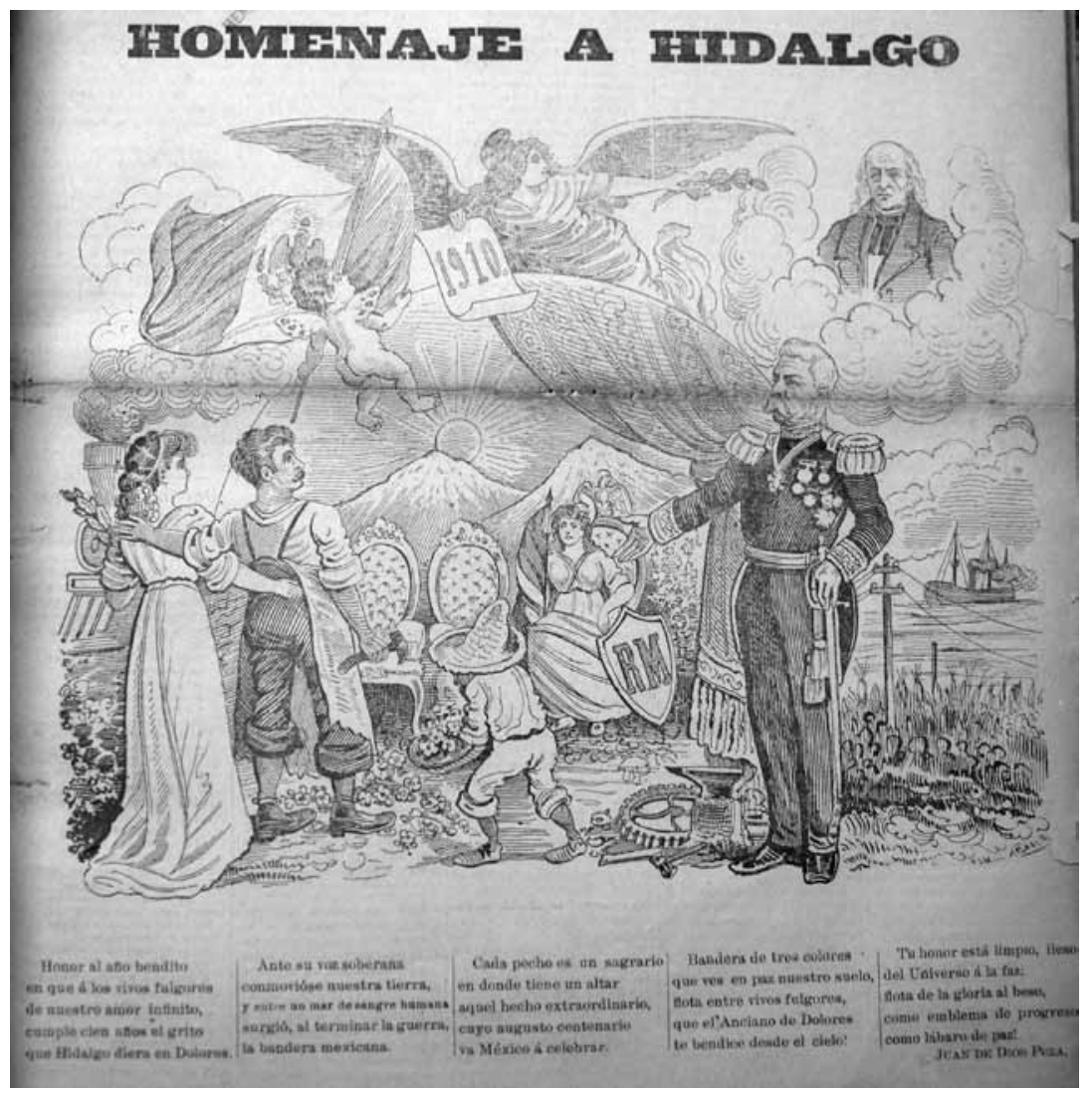

“Homenaje a Hidalgo", San Lunes (3 ene. 1910). 
Como hemos podido observar con el estudio de estas imágenes, la intención de convertir a Díaz en una figura señera de la épica mexicana queda claramente expresada en las caricaturas híbridas y el grabado analizados en estas páginas - entre otras varias, porque también se hizo desde la pintura y la fotografía -, que se produjeron y publicaron en los periódicos a lo largo de toda su vida pública. ${ }^{13}$

\section{ENTRE LA CRÍTICA Y LA DENOSTACIÓN}

Pese a lo que mostraban e intentaban grabar en el imaginario colectivo representaciones visuales como las anteriores, existió una prensa satírica que fue dura detractora de Díaz. ${ }^{14}$ Como contraparte de la figura heroica, y recurriendo a los mismos referentes y elementos usados para construirla, también se publicaron gran cantidad de caricaturas producidas por sus opositores, en las cuales la crítica se hacía de manera frontal y violenta; eran caricaturas profundamente invectivas..$^{15}$ En ellas, en particular en las publicadas a partir de 1876, se acusaban y denunciaban los supuestos métodos y resultados de las acciones de Díaz y de sus aliados, quienes habían accedido al poder y se mantendrían en él con altos costos para el país. Así, desde su primera administración, los periódicos satíricos contrarios a Porfirio señalaban que

${ }^{13}$ El culto a la autoridad presidencial también se construyó por medio de otros recursos, como la celebración de desfiles y la realización de fiestas cívicas.

${ }^{14} \mathrm{La}$ crítica al gobernante se hizo también desde otros segmentos de la prensa de la época. Un estudio interesante al respecto es el de PérezAYón, "La crítica política”, pp. 115-121, 139-141.

${ }^{15}$ Gantús, Caricatura y poder político, pp. 219-220. 
el general se había impuesto por medio de la fuerza. Según lo exhibía una caricatura de La Linterna, publicada el 23 de julio de $1877,{ }^{16}$ venció a garrote limpio a la "Patria" y al "Pueblo", y ambos habían quedado totalmente aprisionados y sometidos por la violencia al imperio de la voluntad del militar y de un gobierno caudillista (imagen 4$).{ }^{17}$

\section{Imagen 4}

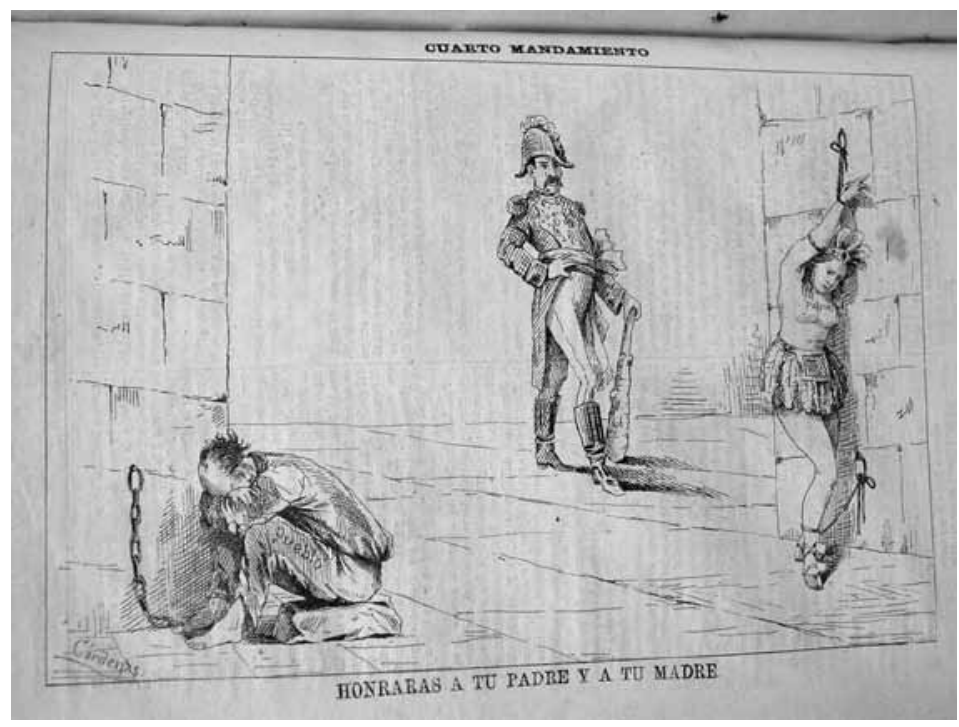

“Cuarto mandamiento", La Linterna (23 jul. 1877).

${ }_{16}$ La Linterna era un semanario "joco-serio", con caricaturas, que se publicó durante unos meses en 1877, de febrero a septiembre. Criticó a Díaz, a los tuxtepecanos y en general a la clase política.

17 Hay que observar en esta imagen la forma en que se representa a la "Patria", pues mientras el "Pueblo" es mestizo, el elemento indígena es el que define el carácter de la primera. 
La caricatura no deja lugar a dudas. Frente al propósito de los correligionarios de Díaz de mostrarlo como héroe de la patria y amigo del pueblo, los opositores se dieron a la tarea de construir otra imagen muy diferente y contrastante. En opinión de sus detractores, el militar representaba una amenaza para México y para sus habitantes. Lo que pronosticaban era el principio de una etapa de gobierno que cancelaba toda esperanza de paz, de desarrollo, de progreso, de independencia. Principios constitucionales, derechos legales e individuales, libertad de pensamiento y de acción, honor, moral y un largo etcétera, parecen haber sido hollados por un régimen que sólo conoce el poder de la fuerza armada y por unos hombres que son capaces de cometer las peores acciones si ello les permite lograr sus objetivos y concretar sus ambiciones, tal cual lo siguiere la desobediencia a un mandamiento esencial enunciado en el título de la propia caricatura: "Cuarto mandamiento". En efecto, la alusión a la religión asociándola con la política es sugerente y provocadora en el marco de una sociedad profundamente católica como la mexicana. ${ }^{18}$ Díaz es presentado como uno de los peores pecadores pues ha faltado nada menos que a uno de los mandamientos fundamentales, al cuarto, que consigna la obligación de honrar al padre y a la madre. El general

18 Aunque había presencia de otras religiones, la mayor parte de la sociedad mexicana profesaba la católica Los principios morales de la misma estaban ampliamente difundidos, quizá más que los propios principios del credo liberal. El uso de elementos y pasajes religiosos fue una constante explotada por la sátira visual. En especial, a partir de la década de 1880, el semanario El Hijo del Abuizote recurrió a ellos con mayor frecuencia, lo que quizá sea un signo de la búsqueda de la caricatura por ampliar su público receptor. Sobre la utilización de símbolos religiosos en la caricatura véase Morales, "La caricatura política", pp. 245-274. 
ha traicionado al pueblo y a la patria, asimilados a los progenitores en sentido cívico, por lo tanto nada se puede esperar de quien no respeta a aquellos a quienes debería amar, procurar y defender por sobre todas las cosas después de Dios. El mensaje es claro y contundente: Díaz es un tirano que avasallará a la nación (imagen 4).

Las imágenes contrarias a Díaz buscaban presentarlo como una especie de villano cuya presencia supondría grandes males y calamidades para el país. En efecto, publicadas en 1877, a tan sólo un año de distancia de las que aparecieran en El Abuizote, varias caricaturas exhiben al militar como un caudillo temible para México. Sin duda, al contrastar unas y otras de esas representaciones, descubrimos visiones profundamente antagónicas sobre la realidad; cada una constituía, a no dudarlo, el sentir y la opinión de individuos y grupos políticamente activos y cada una también era compartida por parte de la sociedad.

Entre otras connotaciones negativas del régimen de Díaz, una que se explotó de manera constante en las caricaturas fue la del riesgo de la imposición de un régimen dictatorial. En términos generales, en la época se entendía por dictadura desde aquel gobierno que para el ejercicio del poder prescindía del texto constitucional hasta aquel en el que imperaba la voluntad despótica. También comprendía al gobierno que atentaba contra la representación nacional, al que se oponía a las instituciones liberales, al que usaba facultades extraordinarias, al que vulneraba los derechos populares, al que abusaba del mando supremo, al que se ejercía de manera absoluta o discrecional, o al que se imponía por la fuerza de las armas. Pero también se consideraba que podían existir otros tipos de dictaduras, incluidas la ilustrada, la 
progresista y la conformada por un gobierno constituyente. En la época, las autoridades mismas podían proclamarse bajo tal régimen. ${ }^{19}$

La acusación de dictador recayó sobre Díaz desde muy temprano en las páginas de los periódicos de humor. En 1877 estuvo motivada por un rumor, del que se habló en varios periódicos de la época, sobre la pretensión de Díaz y sus allegados de promulgar un régimen de ese tipo. Hay algunas imágenes en las que la palabra dictadura aparece directamente sobre la espada que porta Díaz entre las manos. ${ }^{20}$ En la misma época una caricatura publicada el 2 de mayo de 1877 en La Orquesta muestra a Díaz rodeado de sus partidarios - Ignacio Vallarta, Protasio Tagle, entre otros-, dentro de una cantina, en el acto de festejar y brindar mientras el pueblo observa la escena entre indolente y sorprendido (imagen 5). ${ }^{21}$ En "Boliche de la UNIÓN" lo

${ }^{19}$ La discusión sobre la dictadura como forma de gobierno fue constante durante toda la administración de Porfirio Díaz.

En el año 1877, ante el temor de la imposición de una dictadura por parte de los triunfadores de Tuxtepec, el debate en el espacio público cobró especial importancia y ocupó muchas páginas de los impresos de la época. Para ilustrar algunas de las diferentes opiniones sirvan, entre otros, $\mathrm{La}$ Linterna (12 mar. 1877), El Siglo Diez y Nueve (15 mar. 1877) y La Patria (17 nov. 1877). Entre los representantes de la prensa encontramos claros defensores y propagadores de un régimen de ese tipo, así, desde su primer número, La Bandera Nacional, en su "Programa", asentaba: "La primera de las exigencias de la nación es la dictadura ('gobierno constituyente')"; La Bandera Nacional (27 sep. 1877).

20 Entre otros ejemplos, "Segundo mandamiento", La Linterna (9 jul. 1877); o "El pavo", La Mosca (5 abr. 1877).

${ }^{21}$ La Orquesta apareció en diferentes momentos a partir de la década de 1860. Para 1877 se publicaba su cuarta época, que duró sólo unos meses en circulación, y era, entonces, un semanario liberal profundamente crítico del gobierno y, en especial, de Díaz. 
que se festeja es el acto que Díaz acaba de realizar: "una chuza”. El telón de fondo de la mesa de boliche es un rasgado, sucio y maltrecho Plan de Tuxtepec que cuelga tendido entre dos bayonetas que sostiene una figura de gesto demencial. Amparado en sus consignas, las de ese Plan, ${ }^{22}$ y con la bola de la "dictadura", ha derribado los pinos que, humanizados con los rostros de algunos de los legisladores, representan a las Cámaras.

Mediante esa chuza se alude al golpe dado por el gobierno de Díaz al decretar que el Congreso tendría sólo carácter de asamblea legislativa, denigrando así su investidura, convirtiéndolo en un "boliche”, esto es, en una casa de juegos en la que predomina la habilidad y el azar. ${ }^{23}$ De esta "suerte" Díaz impone su voluntad a la de toda la República representada en las Cámaras.

Lo que podemos ver con claridad es que la llegada al poder de un militar, de un caudillo, mediante el uso de la violencia armada, la cual fue capaz de derrocar a un régimen constitucional, provocó en el año 1877 cierto temor: el de la imposición de una dictadura. Y el mismo término de “dictadura” también se utilizó de otras formas, siempre asociado a los riesgos que para la política, para la vida pública y para el país suponían lo que se asumía como las pretensiones del

${ }^{22}$ El Plan de Tuxtepec en su artículo segundo desconocía los poderes federales emanados de las elecciones de 1875, en las que se habían elegido diputados y senadores; y en el quinto establecía que se convocaría un nuevo sufragio para los Supremos Poderes de la Unión a los dos meses de haber ocupado la capital. Plan de Tuxtepec, en Matute, Antología, pp. 322-325.

${ }_{23}$ Luna Argudín, El Congreso y la política mexicana, pp. 180-187. Sobre el tema también Rodríguez KurI, "Los diputados de Tuxtepec", pp. 85-95. 


\section{Imagen 5}

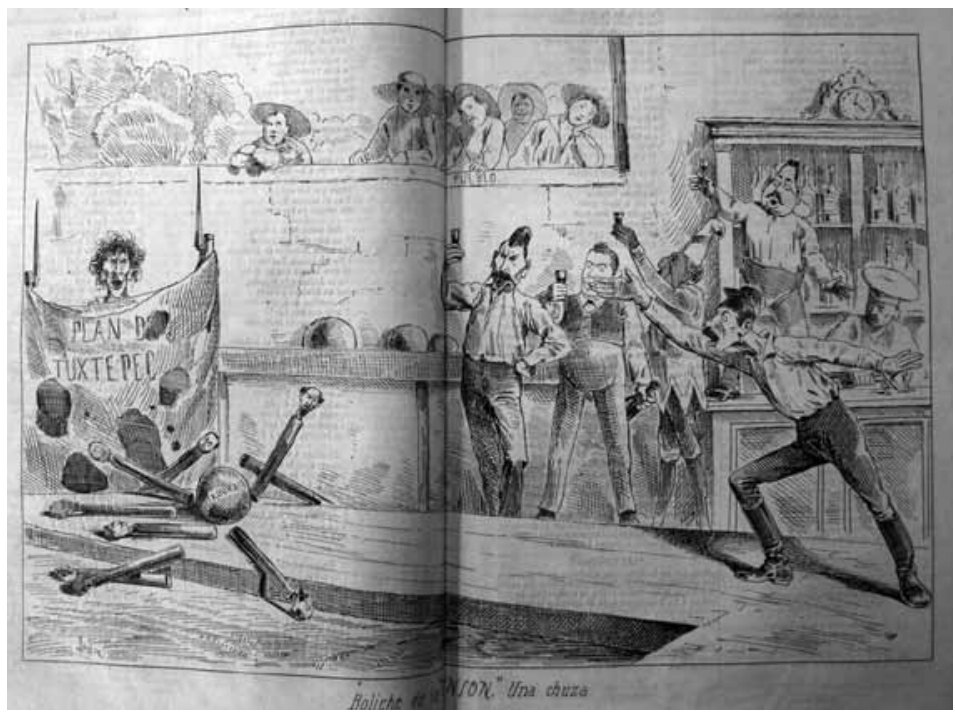

“Boliche de la 'UNION’. Una chuza”, La Orquesta (2 mayo 1877).

general. Así, hacia mediados del régimen, en una caricatura del 21 de diciembre de 1890 de El Hijo del Abuizote, la misma palabra se inscribe en el rifle que sostiene entre sus manos y con el cual dispara el propio Díaz para aniquilar a la patria y a la libertad (imagen 6).

La caricatura es por demás elocuente. Díaz aparece transformado en una especie de ángel del mal que domina el escenario nacional con su política de terror. La ironía se acentúa con la leyenda de "el ángel pacificador" inscrita en las alas con las que se le dibuja y con el hecho de que está parado encima de la "oliva de la paz" transformada en un cañón que dispara balas de "terror, tiranía, gabelas, despo- 


\section{Imagen 6}

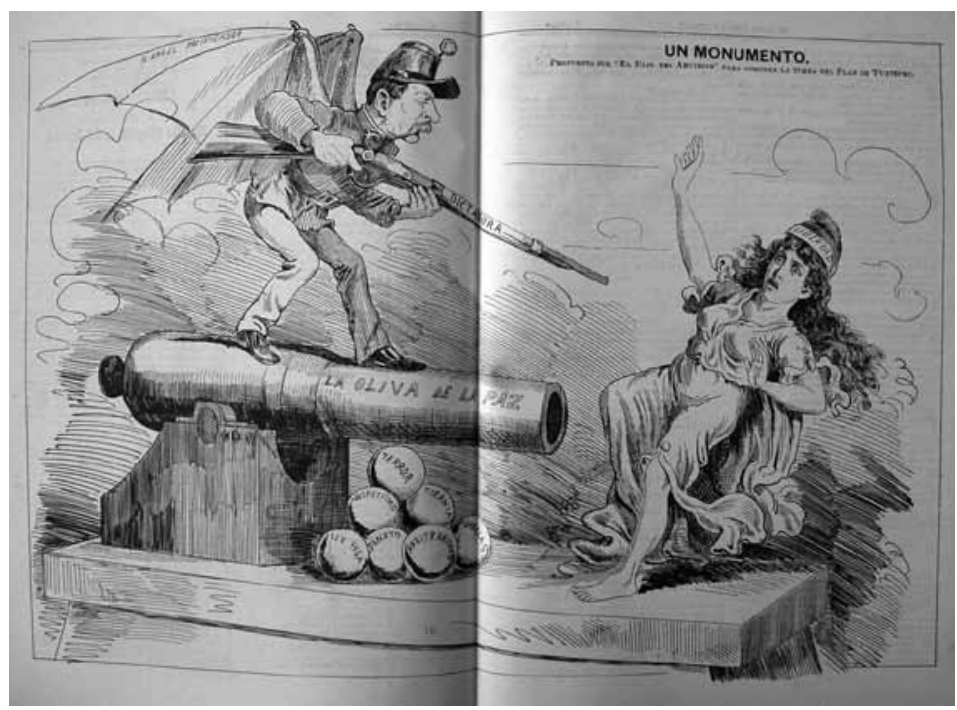

“Un monumento”, El Hijo del Abuizote (21 dic. 1890).

tismo, ley fuga, asesinato y arbitrariedades". Ése es el monumento "para coronar la tumba del Plan de Tuxtepec" que proponen los redactores de El Hijo del Abuizote. ${ }^{24}$ Esto es, con esa y otras imágenes producidas por el semanario se persigue consolidar la idea de que los 14 años de administraciones encabezadas por Díaz y sus correligionarios, tras el triunfo de la causa tuxtepecana, se han caracterizado

${ }^{24}$ El Hijo del Abuizote inició su publicación en agosto de 1885. Inscrito también en el credo liberal, desde sus páginas hizo una constante crítica a las autoridades, incluidos desde funcionarios de los ayuntamientos hasta gobernadores y el presidente, aunque el objeto principal de la misma fue variando en el tiempo. A Díaz lo criticó más o menos de forma permanente, aunque en diferentes tonos y matices. 
por el uso de la violencia como estrategia de gobierno. Así, la caricatura persigue propalar la idea de que sólo mediante una dictadura, entendida como un régimen que ha conculcado todos los derechos constitucionales y sembrado el miedo en la población, ha podido Díaz mantenerse en el poder.

La concepción del término dictadura, en el sentido de su definición en los diccionarios, no varió mucho a lo largo de la segunda mitad de la centuria decimonónica, ${ }^{25}$ pero en lo que respecta a la discusión pública fueron perdiendo fuerza las connotaciones favorables e imponiéndose las negativas - a las que hemos aludido antes - . En lo relativo a la forma de mostrarla en la caricatura respecto a Díaz y su gobierno se pueden observar transformaciones importantes, pues pasa de ser una pretensión ridícula, y casi patética, según la pintaba La Orquesta en 1877 (imagen 5), a algo temible, cimentada en la fuerza del militarismo, como se muestra en El Hijo del Abuizote en 1891 (imagen 7). ${ }^{26}$ Años más tarde, la idea no sólo continuaba vigente, sino que se había

${ }^{25}$ En los diccionarios de la Real Academia Española de los años 1869, 1884 y 1899 el significado de dictadura y dictador fue prácticamente el mismo. En 1869 se definía “Dictador. Magistrado supremo entre los antiguos romanos, que elegían o nombraban los cónsules en los tiempos peligrosos de la república para que mandase como soberano. También se han sometido temporalmente a un DICTADOR algunas repúblicas de América”. Para las ediciones de 1884 y 1899 se anotó un cambio en su parte final: "En algunas repúblicas modernas, magistrado supremo con facultades extraordinarias como las del dictador romano".

En 1869 se definía "Dictadura. La dignidad de dictador, su ejercicio y duración”. Para 1884 y 1899: "Dignidad y cargo de dictador. Tiempo que dura”. Diccionarios, 1869, 1884, 1899.

${ }^{26}$ En los periódicos también se fue consolidando la idea de una dictadura en sentido negativo, en especial al iniciar la siguiente centuria; ejemplo de ello es Regeneración, que usó reiteradamente el concepto para definir 
afirmado; algunos impresos satíricos la presentaban como una realidad: el gobierno, un gobierno caudillista, no era otra cosa que una dictadura. ${ }^{27}$

Algo más conviene comentar de ambas caricaturas: la forma en que se representa o alude al Plan de Tuxtepec y sus significados. Mientras en la imagen 5, en 1877, aparece maltratado pero vivo, en tanto sirve para justificar las acciones del gobierno, para 1891 el mismo está ya muerto y enterrado como consecuencia de las políticas desarrolladas durante casi tres lustros. En efecto, amparado en las consignas del Plan llegó Díaz al poder, pero desde el inicio, algunas de ellas violentaban el estado de derecho. La revolución de Tuxtepec, si bien se ostentaba como un movimiento defensor de la Constitución, atentó, de origen, contra un régimen legal al desconocer al presidente y demás autoridades de los otros poderes; quizá por ello se le pintaba como una bandera manchada y desgarrada. Y el más importante de sus principios, el de la no reelección de los gobernantes, con el correr de los años fue quedando en el olvido y se le traicionó repetidamente - en la letra de la ley y en la práctica-; quizá por ello al vislumbrarse la tercera reelección de Díaz, que tendría lugar en 1892 (segunda continua y cuarta elección en suma: $1877,1884,1888)$, se podía decretar el deceso oficial del tuxtepecanismo.

La imagen negativa de Díaz y su gobierno se construyó también desde la gráfica visual a partir de otros dos elementos fundamentales. Uno, la asociación del presidente con el

al gobierno de Díaz y dio amplio espacio a la discusión del término entre 1901 y 1907.

27 "Veinte años después (de dictadura)", El Hijo del Abuizote (7 abr. 1901). 
militarismo, la cual permitía proyectarlo como el que había logrado mantenerse en el poder únicamente por medio de las armas. El otro, la asociación del general con su espada, permanente compañera, a la que algunos impresos bautizaron como La Matona, la cual fue adquiriendo dimensiones monstruosas hasta llegar a convertirse en el mismo Díaz. ${ }^{28}$ La producción de caricaturas en torno a estas dos críticas fue profusa, en particular la que se construyó y difundió desde las páginas del semanario El Hijo del Abuizote. En ocasiones las dos características eran explotadas en la misma representación como símbolo máximo del poder de Díaz que se imponía a toda la nación y a todas las voluntades, como es el caso de una caricatura publicada en ese impreso el 8 de marzo de 1891 (imagen 7).

Destaca en esta representación el hecho de que dos de las principales fuerzas partidistas emanadas del tuxtepecanismo, que dominaban o habían dominado el espacio político y la vida pública por tres lustros, esto es, el "gonzalismo" y el "porfirismo", fueran caracterizadas como cañones, enfilados entre el terror y el militarismo. El militarismo, como lo siguiere la colocación de los cañones y la perspectiva de los mismos propuesta en la imagen, es el sistema que impera en el país y con el que culmina - a donde ha conducidola trayectoria gubernamental encabezada por esos caudillos emanados de la aludida rebelión. La violencia es pues la estrategia, según denuncia la caricatura, con la que la polí-

${ }^{28}$ El tema de la asociación de Díaz con la espada lo hemos desarrollado en trabajos previos, GANTús, Caricatura y poder político, pp. 157-165 y "Porfirio", pp. 205-225. Por ejemplo, una caricatura de 1892 mostraría a La Matona, que se ha convertido en Díaz, asomando por un balcón, "Notas antireeleccionistas", El Hijo del Abuizote (10 abr. 1892). 


\section{Imagen 7}

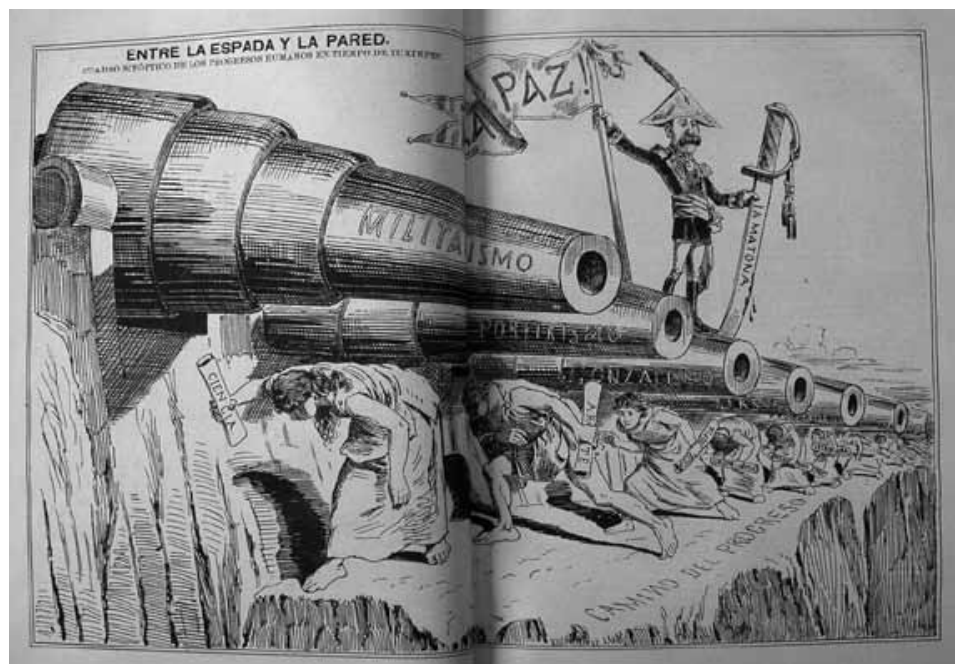

"Entre la espada y la pared. Cuadro sinóptico de los progresos humanos en tiempos de Tuxtepec", El Hijo del Abuizote

(8 mar. 1891).

tica y los políticos sojuzgan todos los elementos del saber y de la libre expresión que hacen, o harían, posible el camino del progreso, tales como "la ciencia, las artes, la filosofía, la jurisprudencia, el periodismo y la tribuna”. Todos esos actores avanzan con dificultad por un sendero estrecho y se encuentran atrapados entre ese poder opresor, que los lleva a marchar encorvados y con gran esfuerzo, y el desfiladero: riesgo y destino de la ruta que transitan. Una ruta trazada por un gobierno que insiste en cobijarse en la bandera de "La paz"; una paz a la que, sin duda alguna, se contrapone y desdice claramente la sangre que escurre por el filo 
de la gigantesca espada que el militar sostiene en una de sus manos y que lo iguala en tamaño (imagen 7).

La sangre agrega un sentido dramático a la escena. Dramático y poco común en la caricatura de la época. Vale aquí señalar que el detalle de mostrar la espada ensangrentada constituye una estrategia visual de gran potencia que seguramente se traducía en un importante impacto sobre la percepción de los receptores. Estrategia que, sin embargo, hasta donde nuestra experiencia nos permite observar, fue escasamente utilizada en la sátira visual de los impresos periódicos en México, pues si las armas se representaron de forma reiterada, casi siempre fueron mostradas en términos bastante asépticos: había armas, pero no había muertos; había armas, pero no había sangre; había armas que se desenvainaban o disparaban, pero no se explicitaban los efectos de tales acciones. ${ }^{29}$ En general, la caricatura mexicana decimonónica se caracterizó por contenidos en los que dominaba lo que podríamos llamar un cierto pudor; así, por ejemplo, se evitaba casi cualquier alusión de tipo sexual o el uso de elementos que resultaran, o pudieran resultar, francamente agresivos a la mirada pública. ${ }^{30}$ En este sentido, podemos aventurar que predominaban en casi toda la prensa, incluida la satírica, límites muy precisos determinados por una especie de horizonte moral que no se transgredía.

${ }^{29}$ La exhibición de elementos francamente grotescos y violentos fue, en cambio, mucho más frecuente en publicaciones de tipo popular, desde folletos hasta hojas sueltas.

30 A diferencia de las caricaturas francesas, inglesas o alemanas, producidas desde el siglo xviII, por ejemplo, en las que las representaciones con contenidos escatológico y sexual, bastante explícitos, eran comunes. 
Pero también las posibilidades de crítica estaban condicionadas por parámetros legales precisos consignados en el Código Penal. ${ }^{31}$ La legislación imponía límites en ese sentido y los miembros de la prensa tomaban precauciones para no ser imputados en términos judiciales. La codificación establecía, entre otras aristas, el respeto a la vida privada de los representantes populares y funcionarios públicos, así como, en general, el cuidado de no afectar en lo individual el honor de las personas. ${ }^{32}$ Esto es, si bien la caricatura se valió y exhibió constantemente diversas formas de violencia, casi siempre se cuidó de preservar la manera en que lo hacía, dejándola insinuada más o menos expresamente, pero sin explotar toda su potencia. Consideramos que,

31 Varios de los delitos consignados en el Código Penal estaban relacionados con la difusión de dichos u opiniones manifestados, entre otras cosas, mediante impresos, por lo que el mundo de la prensa quedaba sujeta a ellos. Así, del "Libro tercero. De los delitos contra la reputación", interesan a este tema el "Título tercero. Delitos contra la reputación”, el "Título sexto. Delitos contra el orden de las familias, la moral pública o las buenas costumbres", el "Título octavo. Delitos contra el orden público", el "Título décimo. Atentados contra las garantías constitucionales" y el "Título decimocuarto. Delitos contra la seguridad interior". Código Penal, 1872.

${ }^{32}$ La codificación daba forma al principio consignado en el documento constitucional de 1857, que en su artículo séptimo señalaba: “[...] la libertad de imprenta $[. .$.$] no tiene más límites que el respeto a la vida privada,$ a la moral y a la paz pública [...]”. Constitución, 1857.

Cuando en 1882 tuvo lugar la reforma del artículo séptimo constitucional se discutió en las cámaras el tema de la crítica a los integrantes del aparato gubernamental y administrativo, distinguiéndose el carácter del funcionario público de su persona en lo particular, aceptando que la prensa tenía derecho a criticar la actuación de los primeros pero sin tocar el ámbito de sus vidas privadas. Sobre el tema, GanTús, Caricatura y poder político, pp. 280-303. 
sin desconocer la impronta de la legislación, soslayar el uso de ciertos recursos visuales, en especial los de tipo sexual, pero también los de la exhibición de formas de violencia - tales como sangre, cadáveres, descuartizamientos, etc. que pudieran resultar ofensivos a la sociedad mexicana, era, en buena medida, el motivo de que no se utilizaran. Y ese entendido de lo que pudiera resultar agresivo a la sociedad está ligado, sin duda, a un sentimiento común de época.

Si el impacto visual de la caricatura "Entre la espada y la pared” no fuera suficiente, la ironía se acentúa con el subtítulo que reza: "Cuadro sinóptico de los progresos humanos en tiempo de Tuxtepec" (imagen 7). ${ }^{33}$ La contradicción entre el "dicho" y el "hecho" de las autoridades se patentiza en la representación. La denuncia es clara, los gobiernos

33 Este subtítulo remite, claramente, a la obra de Jean-Antoine Condorcet, Esquisse d'un tableau historique des progrès de l'espirit humain, publicada en 1794, tras la muerte de su autor. Conocido en español como Bosquejo de un cuadro histórico de los progresos del espíritu bumano, el uso de este referente permite constatar los vínculos que intelectuales y publicistas mantenían con la cultura francesa, así como corroborar la importancia de los circuitos de circulación de información.

El traje militar usado por el ejército mexicano, y con el que está caracterizado Díaz, estaba inspirado en el francés. Así la representación del general recuerda la pintura de Antoine-Jean Gros, de fines del siglo xviII, Bonaparte en el puente de Arcole, por el atavío, pero en particular por la coincidencia en los elementos que portan ambos personajes: un estandarte en una mano y una espada en la otra. El bicornio, también parte del vestuario militar mexicano, por el detalle de la flecha remite a otro momento de la historia militar del país, al de la etapa santanista, una estrategia para asimilar a Díaz con Antonio López de Santa Anna, también general y expresidente, señalado reiteradamente como dictador. Sin embargo, ese mismo bicornio constituye un detalle importante de la ridiculización del personaje, en especial al contraponerse con el elegante traje que porta, pues se trata de un pobre remedo hecho de papel. 
tuxtepecanos han significado para México una especie de era oscura que ha sumido al pueblo en el atraso y la barbarie al arrebatarle el desarrollo de todos los géneros que permiten cultivar el espíritu y la razón. Han quedado pues conculcados el conocimiento, el saber, el pensamiento, la lógica, las leyes, la creatividad, la libre expresión del pensamiento en su conjunto. No hay futuro para la patria; México ha sido secuestrado por el terror que los militares imponen como sistema de gobierno.

Si una parte de la prensa y de la gráfica satírica se esforzó en construir la imagen épica de Díaz, otra parte, en cambio, la deconstruyó recurriendo a los mismos referentes y a los mismos elementos propuestos por los primeros, pero utilizándolos en sentido inverso. Así, planes revolucionarios, rebeliones, derrocamiento de autoridades, defensa de la patria, asociación con el pueblo, uso de las armas, entre otros varios asuntos, fueron explotados de uno y de otro lado con sentidos diametralmente opuestos. Observamos pues dos versiones antitéticas, la producción de dos realidades, de dos construcciones de la realidad que se contradicen y contraponen. Dos miradas que marcaron las visiones que sobre el personaje se construyeron en su momento y que fueron emuladas por la historiografía, en especial la posrevolucionaria.

\section{¿EXCULPACIÓN O CONDENA? \\ UNA REGIÓN DE DIFÍCILES CONTORNOS}

El principio básico de la sátira visual es que busca explotar claramente la ridiculización de lo que es o de quien es el objeto de su crítica. Sin embargo, como hemos visto en 
algunos de los casos expuestos hasta aquí, en ese mismo espacio pueden convivir el halago y la crítica; desde un mismo recuadro se puede exaltar a unos actores o sucesos y denostar a otros. La mayor parte de las veces, en una caricatura es posible identificar a cuál personaje o situación se pretende apoyar y a cuál atacar, pero en realidad esto no siempre es así. Lo cierto es que hay imágenes satíricas de difícil definición, en las que no siempre es clara la intención que se persigue; se trata de caricaturas dudosas. Para ejemplificar la ambigüedad que puede existir en una caricatura, hemos seleccionado una publicada en la etapa final del régimen, en la que se representa a Díaz de tal forma que su desciframiento resulta muy complejo (imagen 8 ): ¿ je busca en ella exculparlo de su responsabilidad como gobernante o condenarlo por su actuación?

Esta caricatura representa una inigualable oportunidad para reflexionar en torno a un tema fundamental del periodismo de la época - del periodismo de cualquier época-, un tema que rebasa al periodismo de humor satírico para abarcar a todo el conjunto de la prensa: el de las estrategias de crítica a la autoridad que se despliegan desde las páginas de los impresos, así como la relación de ésta con la censura, esto es, con los límites que impone un régimen - cualquiera que sea su sello - y la manera, las maneras, de transgredirlo sin enfrentarlo abiertamente. ${ }^{34}$ Cuando la

${ }^{34}$ Esta misma problemática la encontramos en casi todas las expresiones de las artes producidas en países bajo regímenes dictatoriales, autoritarios o represivos. Muchos artistas recurren a la estrategia de "disimular" sus contenidos de tal suerte que, por ejemplo, lo que se presume una simple canción de amor es en realidad una crítica al sistema. El uso de esa táctica responde a la necesidad de, por un lado, evitar la censura que de otra 
represión despliega su sombra, el temor conduce a intelectuales, artistas, pensadores, periodistas y escritores, lo mismo que al ciudadano común, a valerse de vías alternas a la franca exposición de sus opiniones - en particular las políticas - para poder manifestar sus posiciones, hacer públicas sus posturas. ${ }^{35}$

La crítica se mueve entonces en los márgenes del sistema y explora, con mayor o menor discreción, con más o menos fineza, con distintos niveles de agudeza, los límites en que puede desarrollarse. Esto es, en el marco de la prensa, el publicista prueba hasta dónde y cómo se pueden traspasar los terrenos de la censura, implícita o explícita, legal o no, que imponen las autoridades. En el contexto del régimen, es posible descubrir que la crítica - social y políticase ejercía de muy diversas formas, pero se ejercía, y que los considerados "amigos", "aliados", "promotores" o simplemente aquellos "alineados", no lo eran necesariamente ni siempre por convencimiento - aunque sin duda los había-; y observamos que entre quienes mantenían una postura de adhesión abierta al régimen, podemos encontrar, a veces, atisbos de disidencia y hasta de provocación. Una crítica puede ser sutil o velada, pero de ninguna manera casual, ni ingenua; es plenamente consciente y es, también, la declaración, al menos, de un mínimo atrevimiento frente al poder.

forma impediría su circulación y, por otro, a la exigencia de salvar al autor de las consecuencias que tendría la franca exhibición de la crítica.

35 En el caso mexicano, refiriéndose al periodismo, y en particular al discurso del Diario del Hogar, Pérez-Rayón apunta que "las tácticas para criticar a Díaz no están ausentes, pero en general son muy cautelosas o indirectas". Aunque se reconoce que también hubo crítica explícita. Pérez-RAYón, “La crítica política”, pp. 117-118. 
Producida en el marco de un régimen donde el ejercicio de las libertades tenía tintes complejos, con respuestas gubernamentales represivas frente a las expresiones discrepantes, la crítica se dibuja - y usamos el término dibujar con plena conciencia - con contornos a veces difusos. Así, la caricatura que hemos seleccionado, publicada en 1909 en el impreso San Lunes, representaba una escena en la que, aparentemente, el pueblo trabajador apelaba a Díaz para denunciar los abusos patronales contra el proletariado (imagen 8). ${ }^{36} \mathrm{El}$ semanario San Lunes se presentaba como independiente, aunque en 1910 haría campaña en favor del presidente - lo vimos en ese grabado publicado en sus páginas que analizamos en el primer apartado (imagen 3 ) - . En realidad, como muestra la gráfica satírica que aquí exponemos, este periódico, o al menos sus dibujantes, podían asumir posturas a veces contradictorias. La representación de Díaz en esa caricatura lo es. Se trata de una imagen de mensaje vago cuyos contornos y matices, en lo que toca a la crítica política - porque incluye también crítica social evidente-, son difíciles de identificar y precisar. Es una caricatura particular porque la definición de su contenido se sitúa en una zona difusa, en la que la elucidación del mensaje juega un papel central, pero depende, casi exclusivamente, de la opinión de quien la recibe. La imagen encierra, a partir de lo que se pinta, dos posibles lecturas. Esto es, debemos detenernos a considerar si se trata de una forma de exaltación o

\footnotetext{
${ }^{36}$ La caricatura es producto del ingenio de Posada, quien en general mostró respeto por la figura de Díaz. Sin embargo, identificado con la situación y los intereses de la clase trabajadora, sí atacó de manera reiterada al sector empresarial. En un importante número de imágenes Posada denunció los abusos y la explotación de los patrones contra los trabajadores.
} 


\section{Imagen 8}

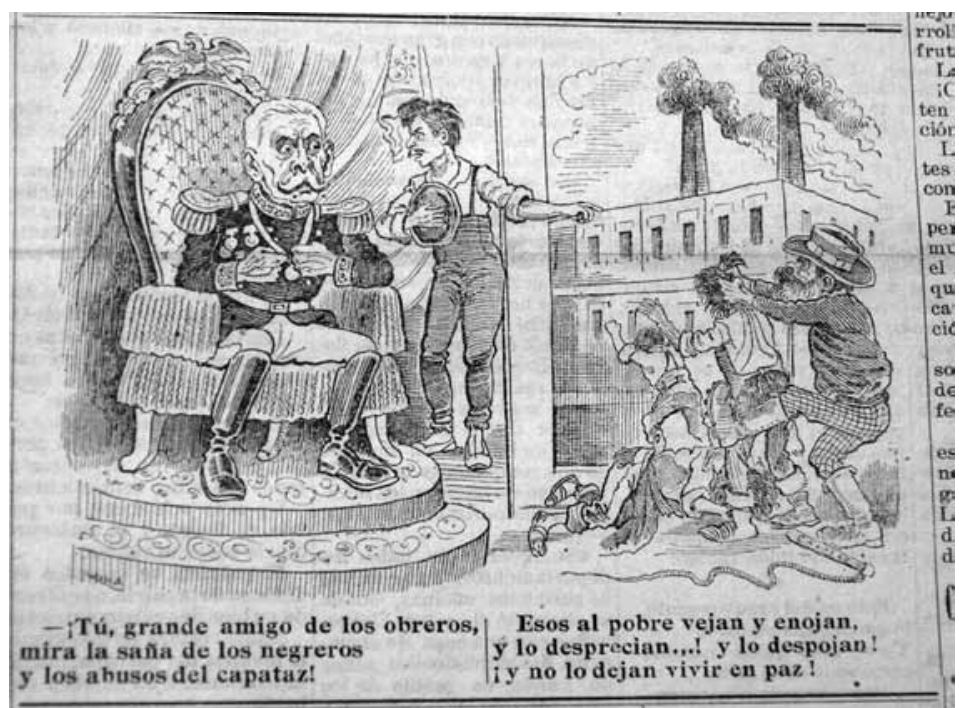

Sin título, San Lunes (20 dic. 1909).

de una burla a Díaz. Y en ese contexto es necesario preguntarse si la caricatura puede mantenerse en una zona neutral. Al respecto aventuramos una respuesta: sin duda, aunque ello resulta muy difícil, es posible, y la alternativa consiste en dejar buena parte de la lectura de su contenido a la interpretación del receptor.

La imagen que nos ocupa tiene varias lecturas posibles. Una primera es la exculpación. Durante gran parte del gobierno encabezado por Díaz se tejieron relaciones entre la administración federal y el mundo del trabajo: ${ }^{37}$ se crearon

37 Sobre el tema remitimos al texto de Gutiérrez, El mundo del trabajo. 
vínculos desde el gobierno con la clase trabajadora - en especial con las organizaciones mutualistas-. Así, se promovían manifestaciones obreras para celebrar el cumpleaños del presidente, conmemorar la batalla del 2 de abril o para apoyar sus sucesivas reelecciones. ${ }^{38} \mathrm{~A}$ cambio de su apoyo, y de la legitimidad que esto daba al régimen, los líderes obreros - y quizá los propios trabajadores - creían obtener la protección del gobierno, en un sentido tradicional y paternalista. En este contexto, desde las páginas de diversos impresos ligados al universo trabajador se produjeron cantidad de dibujos, grabados y caricaturas en las que la figura presidencial era exaltada como la del amigo y protector del obrero. ${ }^{39}$

En esa lógica, lo que podemos ver entonces en la caricatura del San Lunes es al militar transfigurado en el "gran amigo de los obreros” que, sentado en la silla presidencial,

${ }^{38}$ En uno de los varios ejemplos que apunta Gutiérrez señala: "El paso de los manifestantes por la sede del poder ejecutivo, la presencia del Presidente en el balcón y los vivas pronunciados por los trabajadores simbolizan los comienzos del culto personalista de Díaz, la exaltación de la figura presidencial que encontraría en la movilización de los obreros y artesanos mutualistas una fuente de legitimidad y unanimidad". GuTIÉRrEZ, El mundo del trabajo, p. 78.

39 Esto lo ha mostrado Barajas en casos como el de El Periquillo Sarniento o La Guacamaya. Sobre la forma en que algunos impresos ligados al mundo del trabajo presentaban a Díaz, apunta: "en más de una ocasión, las revistas obreras mutualistas ha[cían] loas del ministro de Hacienda José Yves Limantour o de Bernardo Reyes y pint[aban] a don Porfirio como el gran protector del obrero". BARAJAs, Posada: mito y mitote, p. 214. Sobre los vínculos del gobierno con los trabajadores González Navarro destaca el hecho de que Manuel Romero Rubio, durante muchos años secretario de Gobernación de Díaz, fue presidente de asociaciones obreras, lo que evidencia el uso político de esas mutuales. GonzÁLEZ Navarro, El porfiriato. La vida social, p. 346. 
escucha entre sorprendido e indignado la exposición de la situación que impera en las fábricas, que le transmite un enojado pero respetuoso obrero. Se entera así, lo que hace suponer que desconocía los sucesos - estrategia para descargar al mandatario de su responsabilidad en conflictos de ese tipo-, de las vejaciones, los agravios y las humillaciones que los trabajadores sufrían a mano de negreros y capataces. ${ }^{40} \mathrm{La}$ actitud del gobernante, un ligero impulso que lo lleva casi al borde del asiento, los puños cerrados sobre el pecho, parecen sugerir indignación y que actuará de inmediato para tomar medidas que pongan freno a tales actos. Así, será él quien logre defender y hacer respetar los derechos de los trabajadores. De esta suerte, la imagen, fechada en diciembre de 1909, no sólo obviaba las pasadas, y aún recientes en el momento, huelgas de Cananea (Sonora, 1906) y Río Blanco (Veracruz, 1907), y la existencia de otros conflictos que durante el mandato de Díaz afectaron y perjudicaron a la clase trabajadora y al pueblo en general, sino que, en realidad, parecía querer revertirlas: borrarlas de la memoria del lector. Con esta imagen se pretendía desdibujar el hecho de que el mismo presidente, cuya intervención solicitaron los obreros de Río Blanco, favoreció con su posición a los empresarios y ordenó el regreso al trabajo desconociendo el reclamo de mejores condiciones laborales. ${ }^{41}$

Pero si es cierto que durante el régimen se construyó una relación entre el gobierno y los trabajadores, que se quiso

40 Sobre las condiciones del trabajo fabril véase González Navarro, El porfiriato. La vida social, pp. 280-297.

${ }^{41}$ Como se puede notar la firma del caricaturista, José Guadalupe Posada, aparece invertida, seguramente por un error de impresión que alteró la correcta presentación de la imagen. 
presentar como positiva para ambos, también es cierto que hubo quien la denunció como falsa y manipuladora. Entre los críticos del gobierno, esa asociación fue vista como una fuente de beneficios para unos cuantos líderes y de prestigio mal habido para el gobierno. ${ }^{42}$ Esto es, desde la mirada de los opositores, quienes ganaban con esa unión eran los políticos, pero de ninguna manera los trabajadores, que continuaban viviendo en condiciones deplorables. Para los detractores del régimen, Díaz utilizaba a los obreros pero no les concedía nada a cambio.

En este sentido una segunda lectura factible de la caricatura es la de la condena. Estaríamos entonces frente a una ironía matizada que surge de evidenciar el aparente desconocimiento del gobernante sobre las condiciones que imperan en las fábricas, lo que en realidad nadie podía creer, ni aun suponer. ${ }^{43} \mathrm{Si}$ alguien conocía bien la situación y había

42 Para la década de 1880 Gutiérrez muestra los casos del militar Hermenegildo Carrillo y de Pedro Ordóñez, presidente de la Convención Radical Obrera, el primero, y dirigente del Gran Círculo de Obreros, el segundo. Ambos operaban como mediadores en la labor de subordinar al contingente laboral a los intereses de las autoridades. GuTiÉRREZ, El mundo del trabajo, p. 48. En lo que respecta a la denuncia desde la sátira visual, a lo largo del régimen se produjeron varias caricaturas que mostraban a diversos personajes que servían como articuladores entre el gobierno y los trabajadores. La caricatura denunciaba, generalmente, el uso que los primeros hacían de los segundos; así, por ejemplo, "Preludio del Carnaval", El Hijo del Abuizote (6 feb. 1887), o "Al son que les tocan, bailan", México Gráfico (3 mar. 1889).

${ }^{43}$ Imposible, por ejemplo, resultaría que el mandatario desconociera el gran número de huelgas que a lo largo de los años de su gobierno se registraron en distintos estados del país y el Distrito Federal, llegando a sumar, en opinión de González Navarro, alrededor de 250. GonzÁLEZ Navarro, El Porfiriato. La vida social, 1957, p. 298. 
tomado partido en reiteradas ocasiones en favor de la clase patronal/empresarial era, por supuesto, Díaz. Hay también una carga de ridículo, pero éste está apenas sugerido por el gesto de azoramiento que se dibuja - con el que se dibuja - en el rostro del mandatario al "descubrir” la dramática situación de los trabajadores. Los ojos excesivamente abiertos, casi desorbitados, y la forma en que se levantan las cejas proporcionan al semblante presidencial un sello entre grotesco y risible. Son sólo dos pequeños detalles, pero es tal su efecto que resulta imposible no pensarlos facturados con toda la intención..., la intención de evidenciar al gobernante en toda su negligencia, en su indolencia y abandono de la clase trabajadora. Es tal la “sorpresa” del general que, de tan exagerada, resulta afectada, falsa.

Otro elemento más signaría la carga burlesca del mensaje. El asomo de ridículo también se evidencia en la desproporción que existe entre la figura presidencial y la del obrero, pues aun sentado el mandatario tiene un tamaño descomunal que rebasa al del trabajador que se encuentra de pie a su lado. Aunque podría señalarse que es sólo un asunto de perspectiva, del lugar en el que se sitúa el punto de fuga para poder mostrar a uno y otro en primero y segundo plano, respectivamente, podemos suponer, en realidad, un propósito consciente en el uso de tales asimetrías. Su aplicación remitiría a la idea de un poder gubernamental gigantesco que se proyecta sobre el trabajador, y de alguna forma, en su alianza con las élites, lo sojuzga y aplasta.

La misma ironía, la misma exposición al ridículo se encuentra en el texto que acompaña la imagen, la complementa y refuerza el mensaje: un gobierno lejano del trabajador y, por ende, del pueblo. 
- ¡Tú, grande amigo de los obreros, mira la saña de los negreros y los abusos del capataz! Esos al pobre vejan y enojan, y los desprecian...! y los despojan! ¡y no lo dejan vivir en paz! ${ }^{44}$

El texto, entendido en el mismo sentido que la imagen, serviría para marcar y remarcar no sólo la gran lejanía del presidente con el pueblo trabajador, sino su alianza con los intereses del gran capital. Y serviría para trazar los matices de la imagen de un mandatario que prefiere desentenderse de la situación que impera en el país y solapar los abusos.

Si optamos por entender la caricatura en su segunda posible lectura, vislumbramos el atrevimiento, sutil pero patente, del semanario: la denuncia de la situación, la alusión implícita a las huelgas obreras. Esas expresiones y manifestaciones de descontento y de demanda de derechos laborales, con sus terribles efectos - represión, cárcel, muertos, reforzamiento de condiciones de explotación- pueden considerarse entonces como un punto de inflexión que marcó a la sociedad de la época. Sin duda, la actuación patronal y gubernamental no pasó desapercibida para gran parte de la población y, en particular, para los personajes involucrados con el mundo de los impresos. El mundo obrero consigue una centralidad insospechada y adquiere connotaciones simbólicas: eje y catalizador de las inconformidades - que rebasan las meramente electorales - que se traducirán, y

${ }^{44}$ Sin título, San Lunes (20 dic. 1909). 
encontrarán su punto cúlmine, en la lucha revolucionaría contra el régimen, al cual terminará por deponer.

De cualquier forma, sea una u otra la lectura que elijamos darle a esta caricatura, lo cierto es que la misma evo$\mathrm{ca}$, probablemente, una de las mayores contradicciones del régimen: una era de privilegios para unos pocos que supuso condiciones de gran precariedad, cuando no francamente de pobreza, injusticia y marginalidad, para la mayor parte de la sociedad.

\section{VISIONES ANTAGÓNICAS PERDURABLES}

Los años de gobierno de Porfirio Díaz, pese a las estrategias legislativas y judiciales para imponer límites a la prensa y lograr su control, y a los mecanismos de represión desplegados para ello - legales, extralegales y, en ocasiones, ilegales-, estuvieron marcados por lo que podemos considerar una constante guerra de imágenes impresas producidas y reproducidas en y por los periódicos tanto del lado del contingente de los aliados del gobierno como del de sus críticos y opositores. En el marco de ese enfrentamiento por medio de las representaciones visuales, que incluyeron la caricatura, el grabado y la fotografía - aunque aquí sólo nos ocupamos de las primeras-, la figura del general adquirió diversos matices, los cuales recorrían un espectro que iba del heroísmo al despotismo.

Como hemos podido observar a lo largo de esta exposición, la caricatura política jugó un papel fundamental en la construcción de los imaginarios colectivos respecto a la figura y actuación de Díaz y su gobierno. La sátira visual sirvió tanto para elaborar las representaciones que mostraron 
e hicieron del militar una figura épica, como para exhibirlo como dictador y tirano. Pero también constatamos la factura de una tercera forma de caricatura que se constituyó en otro espacio de denuncia del régimen, de crítica no frontal sino velada. En todos los casos, entre esas representaciones es posible observar una suerte de juego de espejos en el que los mismos elementos, las mismas acciones y actuaciones, las mismas situaciones fueron usadas de un lado y otro con carácter y sentido diametralmente opuestos; así, por ejemplo, se exaltaron las gestas militares hasta darles un tono apologético, pero fueron también la referencia para denunciar el militarismo de Estado.

En el contexto de lo expuesto, vale la pena anotar que con nuestro análisis pudimos mostrar tres formas de expresión satírico visual, tres características que definieron a la caricatura política. Primera, la creación de lo que hemos denominado una caricatura híbrida; esto es, frente a la idea generalizada de que la caricatura siempre atenta contra el referente que exhibe, evidenciamos cómo en un mismo espacio pueden convivir el halago y la crítica, siendo esta última la que le proporciona el acento satírico y burlesco. Segunda, la caricatura invectiva definida por su abierto ataque del referente al que alude y por la carga de violencia explícita que la constituye. Tercera, mostramos la existencia de una caricatura ambigua, en la que la representación ofrece varias posibilidades de lectura y la interpretación del mensaje se deja al espectador.

Mostramos también, con el análisis de las diferentes formas y usos de la caricatura política, que ellas posibilitan el acercamiento a un fragmento de la realidad que las generó, pero que por sí solas no pueden proporcionarnos un 
panorama completo de la época, ni penetrar en toda la complejidad de un régimen político, de sus diferentes momentos, de las transformaciones de una sociedad, ni de sus problemas. Lo que sí hacen es permitirnos descubrir cuáles eran los temas candentes y los personajes relevantes y, en tal sentido, las caricaturas producidas en la etapa muestran que la rebelión de Tuxtepec y la traición a sus principios, el heroísmo militar y la popularidad de Díaz en la lucha contra la intervención francesa, así como el recurso de la mano dura contra la disidencia, el impulso al desarrollo económico y la agudización de las contradicciones sociales provocadas por la industrialización, entre otros, fueron, sin duda, tópicos de gran relevancia. Y sobre todos esos temas las caricaturas tuvieron múltiples visiones y posicionamientos.

$\mathrm{Ni}$ el fin del régimen que encabezó, ni la muerte de Díaz terminaron con la confrontación de imágenes. La literatura y la historiografía posrevolucionaria trazaron una imagen de Díaz muy cercana a la que sus opositores desde la sátira visual construyeron en su época. Una imagen que fue, durante varias décadas, una especie de caricatura del gobernante. ${ }^{45}$ Desde la historiografía se ha tratado de analizar, con mayor o menor rigor académico, el gobierno del general y su propia figura y durante todo el siglo xx y lo que va del xxI, el personaje ha contado con detractores, los más, pero también con apologetas.

${ }^{45} \mathrm{El}$ análisis de esas caricaturas posibilita también descubrir cómo muchos de los temas, sobre todo el tratamiento casi paródico de los mismos, con los que se ha asociado al general y su régimen de gobierno, y que formaron y formarían parte sustancial de la discusión historiográfica, encuentran también su antecedente, cuando no su origen, en las imágenes satíricas producidas en la época. 
¿Fue Díaz héroe o villano? ¿Ambas cosas o ninguna? Sin asumir, como lo quería la caricatura opositora, que Díaz fuera un villano o un dictador, tampoco se puede admitir, como lo querían las imágenes proselitistas, que Díaz fue un héroe, un demócrata. Ciertamente, no se puede afirmar que Díaz haya sido un hombre respetuoso de las leyes a cabalidad, como tampoco se puede asegurar que fuera un liberal radical. Imposible decirlo aunque haya gobernado de la mano de un régimen electoral, se haya desempeñado bajo un sistema constitucional y haya mantenido, en las formas, los preceptos del liberalismo. Y no se puede pretender todo esto porque la historia ha mostrado cómo los comicios tendrían su función política, pero el régimen no era democrático; porque ha mostrado igualmente cómo las leyes se transgredieron innumerables veces y los principios del liberalismo se vulneraron. Por otra parte, también es cierto que Díaz tampoco gobernó únicamente con las armas en la mano - porque gobernar un país, lo que sin duda hizo, requiere de una estructura política compleja que demandó en todo momento de transigir, negociar y conceder-. Pero sí hay que decir que durante los largos años de su presidencia, el gobernante supo usar la fuerza de las armas cuando lo consideró "necesario" para guardar el "orden” y asegurar la "tranquilidad pública": hubo represión, hubo guerra contra los indios que resistían a la "civilización", hubo mano dura contra las manifestaciones de protesta populares. El uso a conveniencia de la fuerza de las armas puede no hacer de Díaz un dictador, no obligadamente, cierto, pero sí lo define como el representante de un régimen autoritario y, conforme se prolongó su estadía en el poder, cada vez más insensible a los problemas sociales y las demandas populares. En eso, algunos recuadros de la sátira visual fueron muy certeros. 


\section{SIGLAS Y REFERENCIAS}

Barajas Durán, Rafael

Posada: mito y mitote. La caricatura política de José Guadalupe Posada y Manuel Alfonso Manilla, México, Fondo de Cultura Económica, 2009.

Casar, María Amparo e Ignacio Marván (coords.)

Gobernar sin mayoría. México, 1867-1997, México, Taurus, Centro de Investigación y Docencia Económicas, 2002.

Código Penal

Código Penal para el Distrito Federal y Territorios de la Baja California sobre delitos del fuero común, y para toda la República sobre delitos contra la Federación, México, Edición oficial, 1872.

\section{Constitución}

Constitución Federal de los Estados Unidos Mexicanos, México, 1857.

Cosío Villegas, Daniel

"El Porfiriato: su historiografía o arte histórico", en Extremos de América, México, Tezontle, 1949, pp. 113-183.

Historia moderna de México, El Porfiriato. La vida politica interior, primera y segunda parte, México, Hermes, 1970 y 1985 .

Diccionario

Diccionario de la lengua castellana por la Real Academia Española, 11a . ed., Madrid, Imprenta de Don Manuel Rivadeneyra, 1869.

Diccionario de la lengua castellana por la Real Academia Española, 12ª . ed., Madrid, Imprenta de D. Gregorio Hernando, 1884 . 
Diccionario de la lengua castellana por la Real Academia Española, 13a. ed., Madrid, Imprenta de los Sres. Hernando y compañía, 1899.

Gantús, Fausta

"Porfirio Díaz y los símbolos del poder. La caricatura política en la construcción de imaginarios", en Cuicuilco, 40 (mayo-ago. 2007), pp. 205-225.

Caricatura y poder político. Crítica, censura y represión en la ciudad de México, 1876-1888, México, El Colegio de México, Instituto de Investigaciones Dr. José María Luis Mora, 2009.

González Navarro, Moisés

El Porfiriato. La vida social, en Daniel Cosío Villegas (coord.), Historia moderna de México, México, Hermes, 1957.

Guerra, François-Xavier

México: del Antiguo Régimen a la Revolución, México, Fondo de Cultura Económica, 1995, 2 tomos.

Gutiérrez, Florencia

El mundo del trabajo y el poder político. Integración, consenso y resistencia en la Ciudad de México a fines del siglo XIX, México, El Colegio de México, 2011.

Luna Argudín, María

El Congreso y la política mexicana (1857-1911), México, El Colegio de México, Fondo de Cultura Económica, 2006.

Matute, Álvaro

Antología. México en el siglo XIX. Fuentes e interpretaciones históricas, México, Universidad Nacional Autónoma de México, 1981.

Morales Flores, Mónica

"La caricatura política en la ciudad de México durante el Porfiriato. El caso de El Hijo del Abuizote. Una aproximación al 
discurso gráfico del semanario", tesis de licenciatura en historia, México, Escuela Nacional de Antropología e Historia, 2005.

Pérez-Rayón Elizundia, Nora

"La crítica política liberal a fines del siglo xIx. El Diario del Hogar”, en Speckman y Agostoni (eds.), 2001.

RODríguez Kuri, Ariel

"Los diputados de Tuxtepec: la administración de la victoria", en Casar y Marván (coords.), 2002, pp. 79-106.

Salmerón, Alicia y Fernando Aguayo (coords.)

Instantáneas de la ciudad de México. Un álbum de 18831884, México, Instituto de Investigaciones Dr. José María Luis Mora, Universidad Autónoma Metropolitana-Cuajimalpa, Banamex, 2013.

Speckman Guerra, Elisa

"Justicia, política y honor: la supresión del jurado de imprenta en el Distrito Federal”, en Salmerón y Aguayo (coords.), 2013, t. I, pp. 197-210.

Speckman, Elisa y Claudia Agostoni (eds.)

Modernidad, tradición y alteridad. La ciudad de México en el cambio de siglo $(X I X-X X)$, México, Universidad Nacional Autónoma de México, 2001.

Tenorio Trillo, Mauricio y Aurora Gómez Galvarriato

El Porfiriato, México, Fondo de Cultura Económica, Centro de Investigación y Docencia Económicas, 2006.

VAladés, José C.

El Porfirismo: historia de un régimen, México, Patria, 1948, 2 volúmenes. 
Hemerografía

El Abuizote, Ciudad de México.

La Bandera Nacional, Ciudad de México.

Diario del Hogar, Ciudad de México.

El Hijo del Abuizote, Ciudad de México.

La Linterna, Ciudad de México.

México Gráfico, Ciudad de México.

La Mosca, Ciudad de México.

La Orquesta, Ciudad de México.

El Padre Cobos, Ciudad de México.

La Patria, Ciudad de México.

Regeneración, Ciudad de México.

San Lunes, Ciudad de México.

El Siglo Diez y Nueve, Ciudad de México. 